\title{
Tools for prioritizing Ecosystem Services provided by fragments forest in the context of cities
}

\author{
Alessandra Leite da Silva \\ Admilson Írio Ribeiro \\ Regina Márcia Longo
}

I Universidade Estadual Paulista "Júlio de Mesquita Filho, Sorocaba, SP, Brasil.

"Iniversidade Estadual Paulista "Júlio de Mesquita Filho, Sorocaba, SP, Brasil.

III Pontifícia Universidade Católica de Campinas PUC, Campinas, SP, Brasil.

\begin{abstract}
Forest remnants are essential in the provision of ecosystem services in cities. However, adequate ecological parameters are still needed to assess them. Because of this, the present work proposes a methodology for assessing the potential of providing ecosystem services by forest remnants in urban watershed based on the application and interpretation of landscape spatial metrics used in Landscape Ecology studies. For that, the environmental indicators (area, central area, circularity index, distance from the nearest neighbor, water springs, land use, and occupation in the surroundings) were evaluated in GIS software and to them, the Hierarchical Process Analysis Method (AHP) was applied to identify the importance of each parameter in the provision of ecosystem services and the priority in each remainder. The study was carried out in a watershed in Campinas/ SP, in which it was found that forest remnants develop, primarily, ecosystem support or habitat services, regulation services, and cultural services.
\end{abstract}

Keywords: Urban forest remnants; spatial analysis; ecosystem services; Hierarchical Analysis of Processes.

São Paulo. Vol. 24, 2021

Original Article

DOI: http://dx.doi.org/10.1590/1809-4422asoc20200012r1vu2021L2AO 


\section{Introduction}

Tropical forests are one of the planet's most complex and important ecosystems because of their great biodiversity and the different ecological roles they play (MORLEY, 2009; FENGLER et al., 2015). The rapid and disorderly growth of urban centers in areas formerly occupied by these forests has negatively affected the quality of life of the population and the biodiversity present in cities and their surroundings.

Besides that, cities are social-ecological systems characterized by complex networks of interacting components, making resilience in these areas a difficult-to-achieve goal. However, in the context of global environmental change characterized by unprecedented and rapid urbanization, the concept of urban resilience is being widely applied to urban planning and decision-making (McPHEARSON et al., 2014; SCHEWENIUSET, MCPHEARSON, ELMQVIST, 2014; CHELLERI, SCHUETZE, SALVATI, 2015; KREMER et al., 2015; BENNETT, 2016; MEEROW et al., 2016).

Places that face problems with increasing urbanization and disordered land use and occupation, as Latin American countries, "forest remnants in urban areas are perhaps the last refuges for protection and conservation of biodiversity, contributing to the improvement of the quality of life by offering a space of culture where humans live with other plant and animal species" (MUÑOZ; FREITAS, 2017).

This occurs not only in Latin America. In Europe has been seen that the urbanization process and the increasing crowding of people in cities have contributed to a growing demand for natural resources such as food, timber, and space for housing, provided by these natural areas (MAES et al., 2015). Besides, the problem is even more serious when it is observed that, at a global level, land conversions occur often at sensitive natural areas such as wetlands, natural areas, and semi-natural ecosystems (LAMBIN; MEYFROIDT, 2011).

Thus, although to know the natural capital and services provided by natural ecosystems is a very useful tool for public policymakers, especially concerning rural and urban management, spatial planning, and protected area management (MEA, 2005), there is still a limited understanding of the role green infrastructure plays to produce Urban Ecosystem Services (UES) (HAASE et al., 2014). The Economics of Ecosystems and Biodiversity Report (TEEB, 2011) highlights the great difficulty local and regional governments face in providing essential municipal services and to consider environmental issues and the value of nature, criteria in development policies.

Before the challenge to balance the different ecosystems, considering local conditions and needs, it is necessary to increase efforts to better understand the dynamics of urban ecosystems and the services provided by the least, as a basis for better urban planning strategies with sustainability criteria. Some ecosystem services are a priority due to the high demand at the local, regional and global scale and the provision of UES at the regional level may improve the resilience of the urban system to disturbances in the long term (MUÑOZ; FREITAS, 2017).

Although the same site cannot provide all types of ecosystem services it can be essentially important in providing some of them. Because of that is important to com- 
plete the diagnosis of natural ecosystems, to identify their fragilities and potentialities in relation to the ecosystem services they provide and/or can provide. As Picharillo and Ranieri (2019) point out, identification of the relevant elements for prioritizing areas is, therefore, only the first step in more cost-effective conservation planning, contributing to the effectiveness of payment programs for ecosystem services.

Therefore, considering the quantification of landscape spatial patterns the landscape metrics are important tools in, but not just for this reason. Applied to natural landscapes, when well analyzed and correlated, such metrics allow us to understand the relationships between patterns and spatial processes of the vegetation and the ecological processes to which they are linked, considering their structural, functional, and composition aspects (LAWLEY et al., 2016; METZER, 2003 apud OLIVEIRA et al., 2015).

In view of the growing discussion about the provision of ecosystem services and the current search for indicators that guide the paths to sustainable development (YOUNG et al., 2014; FREITAS et al., 2013) the present work aims to verify the possibility of evaluating the potential of providing ecosystem services by forest remnants from the application and interpretation of landscape spatial metrics used in Landscape Ecology studies. So, this study acts as an auxiliary tool for decision-making of preservation and conservation of ecosystems, biodiversity, forests and exploitation of the natural potential of natural remnants.

\section{Methods}

\section{The study site}

This work was applied to forest remnants located in a watershed located in the city of Campinas / SP- Brazil. The municipality has become a dynamic hub in the interior region of the State of São Paulo and has undergone radical economic and demographic changes over time; it is currently one of the main metropolises of the country (CAMPINAS, 2018). Campinas covers in its total area six hydrographic basins, with distinct characteristics regarding the use and occupation of the soil. The hydrographic basin considered as a planning unit for the present study is denominated as the Anhumas River Basin and covers an area of approximately $150 \mathrm{~km}^{2}$ (Figure 1). 
Figure 1 - The geographical location of the study area: Anhumas River Basin, Campinas/ SP. Brazil
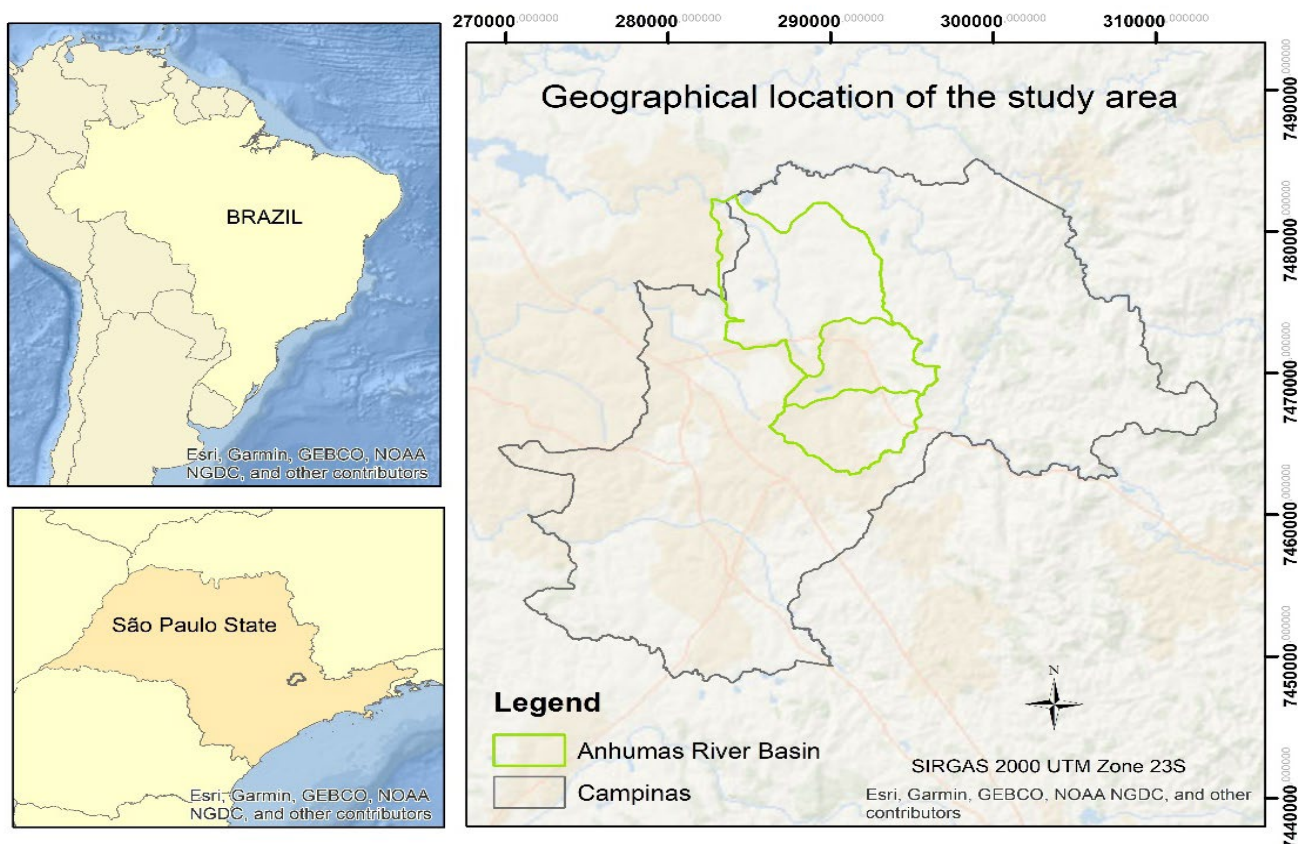

Source: Authors, 2020.

Anhumas River Basin is in the most urbanized areas of the town, being one of the first places of occupation of the municipality. According to Carpi Jr. et al. (2006), a considerable percentage of the environmental problems identified in the municipality of Campinas, such as the contamination of springs, rivers, soil, water scarcity, flood, disorderly occupation of the territory, noise and air pollution, are found in this river basin. The high degree of soil sealing in this basin, especially upstream, are associated with the accumulation of pollutant load (solid waste, domestic and industrial effluents, and excess water from high-grade floods) and taken to the lower region of the basin (BRIGUENTI, 2005; CARPI; DAGNINO; SCALEANTE, 2007). Also, because it is a predominantly urban region, the few forest remnants present in the Anhumas River Basin are highly susceptible to external anthropogenic pressures (SILVA; LONGO, 2017).

Given this, and the need of public managers to implement public policies focused on forest remnants and the provision of ecosystem services, the Anhumas River Basin was chosen as the model basin for the application of the methodology described below. 


\section{Analysis of environmental indicators (Landscape Metrics)}

For the analysis of the environmental indicators, the forest remnants were survey based on the mapping of the natural vegetation of Campinas, carried out by the Municipality of Campinas (PMC) in partnership with the Center for Environmental Studies and Research (Nepam), of the State University of Campinas (UNICAMP) on a scale of 1: 10,000 (CAMPINAS, 2015). For that, it was considered as forest fragments those remaining with phytophysiognomy of the classes: Seasonal Semideciduous Forest; Mixed Forest; Paludosa Forest and Semideciduous Seasonal Forest with small traces of Cerrado.

The selected landscape metrics for the evaluation of these areas were calculated in Geographic Information System software (GIS), they were:

a) Area (AREA): Area of each remnant in hectares (ha). Each remnant was classified, according to their area: very small $(<0.50 \mathrm{ha})$, small $(0.50-1.00 \mathrm{ha})$, medium (1.00-5.00 ha), good (5.00-20.00 ha), and adequate ( $>20.00 \mathrm{ha}$ ) (FREITAS, 2012). For the determination of the "Adequate" class Freitas (2012) was based on the relationship between the interior area and the border greater than 2.5.

b) Centra Area Index (CAI): percentage of the remaining area that corresponds to the central area, disregarding the edge region that is effectively subject to the effects of external pressures, called border effects (HERRMANN; RODRIGUES; LIMA, 2005; PIROVANI et al., 2014; FENGLER et al., 2015, ETTO et al., 2013, CABACINHA; CASTRO, 2009). For this, the remnant areas were recalculated, disregarding the region within $60 \mathrm{~m}$ of the border, as adopted by Calegari et al. (2010). The inconsiderate areas constitute the border areas.

c) Circularity Index (CI): The parameters area and perimeter were used to calculate the Circularity Index $(\mathrm{CI})$, according to Equation I, where $A=$ fragment area $\left(\mathrm{m}^{2}\right)$ and $\mathrm{L}=$ fragment length $(\mathrm{m})$.

$$
C I=\frac{(2 \sqrt{\pi \cdot A})}{L}
$$

This index aims to identify how closely the shape of a circumference is the forest fragment; where: $\mathrm{CI}<0,65$ indicates elongated shape; $0,65 \leq \mathrm{CI}<0,85$ moderately elongated; and $\mathrm{CI} \geq 0,85$ rounded shape. The circular format promotes a minimization of the border area about the total area, reducing the edge effects on the remainder (FENGLER et al., 2015, NETO et al., 2015, ETTO et al. , 2013; RANTA et al., 1998).

d) Distance from the nearest neighbor (ENN): the Euclidean distance (in meters) from a forest remnant to its nearest neighbor. This metric is related to the connectivity of the landscape, as long as after a certain degree of isolation, the biological populations of the fragments begin to show losses in terms of biological flow (MASSOLI et al., 2016; LIMA et al., 2017).

e) Water springs (SPR): To verify the production of water in each remnant we used the mapping of springs carried out in 2003 by the Geographic and Cartographic Institute (IGC) at a scale of 1: 10,000 and updated in 2014 by the Secretariat for Green, Environment, and Development Sustainable Development (SVDS) of the Campinas-SP/Brazil 
at a scale of 1: 5,000 (CAMPINAS, 2018).

f) Land use and occupation in the surroundings (SUR): The analysis of this indicator was carried out for the areas in a radius of up to $175 \mathrm{~m}$ around each remainder. This analysis was performed from Land Use and Land Cover Map of the Hydrographic Unit for Water Resources Management (UGRHI) 5 - Piracicaba / Capivari / Jundiaí (PCJ),), at a scale of $1: 25,000$, with $2.5 \mathrm{~m}$ of spatial resolution with fused bands, and scenes in multispectral mode, from the years 2007 to 2009, and with a spatial resolution of $10 \mathrm{~m}$ (SÃO PAULO, 2013) and aerial images provided by EMPLASA (2010).

Thus, the area around each fragment could be classified according to the intensity of natural landscape modification, in five groups, according to Chaves and Santos (2009): (a) Class 0 , covering natural or almost natural landscapes, with a very low degree of use and occupation of the soil, such as Brazilian Cerrado or forest; (b) Class 1, natural vegetation with a small modification, low degree of use and occupation; (c) Class 2, transition areas, medium degree of use and land occupation, such as parks and planted pastures; (d) Class 3, much modification of the natural landscape and high degree of use and occupation of the soil; characterized by deforested areas, dirt roads, orchards...; and (e) Class 4, completely modified areas, with very high use and occupation of the ground, such as exposed soil, degraded areas, paved streets, buildings, and similar areas.

\section{Determination of ecosystem services}

According to the Millennium Ecosystem Assessment, ecosystem services can be classified into four basic types: (1) Supply services, related to material and energy production, such as: food, raw materials, fresh water, and medical resources; (2) Regulating services, that are provided from the moment when ecosystems begin to act as regulators of some environmental condition, such as, climate and air quality; (3) Support services or habitat since ecosystems provide specific location and conditions for the development and preservation of several species; and (4) Cultural services, that are especially appreciated by local citizens who can benefit aesthetically, spiritually and psychologically from natural ecosystems.

Based on the literature (FERNANDES et al., 2017; FERNANDES; FERNANDES, 2017; MORO; MILAN, 2016; MASSOLI; STATELLA; SANTOS, 2016; SAITO et al., 2016; OLIVEIRA et al., 2015; FENGLER, 2015; SILVA et al., 2015; NETO et al., 2015; PIROVANI et al., 2014; SILVA; MELO, 2014; ETTO et al. , 2013; CALEGARI, 2010; HERRMANN; RODRIGUES; LIMA, 2005; VALENTE, 2005; RANTA et al., 1998; VIANA; PINHEIRO, 1998) it was possible to establish possible correlations between the calculated indicators (Area, Central Area, Circularity Index, Distance from Nearest Neighbor, Springs, and Land use and occupation in surroundings) and potentially favored ecosystem services. Table 1 presents some of the possible correlations highlighted. 


\section{Table 1 - Correlation between landscape metrics and potential ecosystem services in forest remnants*}

\begin{tabular}{|c|c|c|c|c|c|}
\hline \multirow{2}{*}{ Indicators } & \multirow{2}{*}{ Class } & \multicolumn{4}{|c|}{ Potentially associated ecosystem service*** } \\
\hline & & Supply & Regulating & Support & Cultural \\
\hline \multirow[t]{2}{*}{ Area (ha) } & $\begin{array}{l}\text { Large fores- } \\
\text { ted areas }\end{array}$ & $\begin{array}{l}\text { Food } \\
\text { Raw material }\end{array}$ & $\begin{array}{l}\text { Regulation of } \\
\text { climate and } \\
\text { local air quality; } \\
\text { Carbon seques- } \\
\text { tration and } \\
\text { storage; } \\
\text { Moderation of } \\
\text { extreme weather } \\
\text { events }\end{array}$ & $\begin{array}{l}\text { Species habi- } \\
\text { tats; } \\
\text { Preservation } \\
\text { of genetic } \\
\text { diversity }\end{array}$ & Tourism \\
\hline & $\begin{array}{l}\text { Small fores- } \\
\text { ted areas }\end{array}$ & & $\begin{array}{l}\text { Prevention of } \\
\text { erosion and } \\
\text { maintenance of } \\
\text { soil fertility; } \\
\text { Pollination } \\
\end{array}$ & & $\begin{array}{l}\text { Recreation } \\
\text { and mental } \\
\text { and physical } \\
\text { health }\end{array}$ \\
\hline \multirow{2}{*}{$\begin{array}{l}\text { Central Area } \\
(\%)\end{array}$} & $\begin{array}{l}\text { High per- } \\
\text { centage of } \\
\text { nuclear area }\end{array}$ & & & $\begin{array}{l}\text { Species habi- } \\
\text { tats; } \\
\text { Preservation } \\
\text { of genetic } \\
\text { diversity }\end{array}$ & \\
\hline & $\begin{array}{l}\text { Low per- } \\
\text { centage of } \\
\text { nuclear area }\end{array}$ & & & & $\begin{array}{l}\text { Recreation } \\
\text { and mental } \\
\text { and physical } \\
\text { health }\end{array}$ \\
\hline \multirow{2}{*}{$\begin{array}{l}\text { Circularity } \\
\text { Index }\end{array}$} & $\begin{array}{l}\text { More elon- } \\
\text { gated }\end{array}$ & & $\begin{array}{l}\text { Prevention of } \\
\text { erosion; } \\
\text { Pollination }\end{array}$ & & $\begin{array}{l}\text { Recreation } \\
\text { and mental } \\
\text { and physical } \\
\text { health }\end{array}$ \\
\hline & $\begin{array}{l}\text { More roun- } \\
\text { ded }\end{array}$ & $\begin{array}{l}\text { Species habi- } \\
\text { tats; } \\
\text { Preservation } \\
\text { of genetic } \\
\text { diversity }\end{array}$ & & & \\
\hline
\end{tabular}




\begin{tabular}{|c|c|c|c|c|c|}
\hline \multirow[t]{2}{*}{$\begin{array}{l}\text { Distance } \\
\text { from the nea- } \\
\text { rest neighbor }\end{array}$} & \multicolumn{2}{|l|}{$\begin{array}{l}\text { Short dis- } \\
\text { tance }\end{array}$} & $\begin{array}{l}\text { Prevention of } \\
\text { erosion and } \\
\text { maintenance of } \\
\text { soil fertility; } \\
\text { Regulation of } \\
\text { climate and } \\
\text { local air quality }\end{array}$ & $\begin{array}{l}\text { Species habi- } \\
\text { tats; } \\
\text { Preservation } \\
\text { of genetic } \\
\text { diversity }\end{array}$ & \\
\hline & $\begin{array}{l}\text { Too much } \\
\text { distance }\end{array}$ & & $\begin{array}{l}\text { Regulation of } \\
\text { climate and } \\
\text { local air quality }\end{array}$ & & $\begin{array}{l}\text { Recreation } \\
\text { and mental } \\
\text { and physical } \\
\text { health }\end{array}$ \\
\hline \multirow[t]{2}{*}{ Springs } & Yes & $\begin{array}{l}\text { Fresh water; } \\
\text { Food }\end{array}$ & $\begin{array}{l}\text { Prevention of } \\
\text { erosion and } \\
\text { maintenance of } \\
\text { soil fertility }\end{array}$ & & \\
\hline & No & Raw material & & & \\
\hline \multirow[t]{2}{*}{$\begin{array}{l}\text { Land use and } \\
\text { occupation in } \\
\text { the surroun- } \\
\text { dings }\end{array}$} & $\begin{array}{l}\text { Low degree } \\
\text { of use and } \\
\text { occupation in } \\
\text { the surroun- } \\
\text { dings }\end{array}$ & $\begin{array}{l}\text { Food; } \\
\text { Raw material; } \\
\text { Medical resour- } \\
\text { ces }\end{array}$ & $\begin{array}{l}\text { Carbon seques- } \\
\text { tration and } \\
\text { storage; } \\
\text { Moderation of } \\
\text { extreme weather } \\
\text { events; } \\
\text { Biological } \\
\text { control }\end{array}$ & $\begin{array}{l}\text { Species habi- } \\
\text { tats; } \\
\text { Preservation } \\
\text { of genetic } \\
\text { diversity }\end{array}$ & $\begin{array}{l}\text { Tourism; } \\
\text { Aesthetic ap- } \\
\text { preciation and } \\
\text { inspiration for } \\
\text { culture, art, } \\
\text { and design; } \\
\text { Spiritual ex- } \\
\text { perience and } \\
\text { sense of place }\end{array}$ \\
\hline & $\begin{array}{l}\text { High degree } \\
\text { of use and } \\
\text { occupation in } \\
\text { the surroun- } \\
\text { dings }\end{array}$ & & $\begin{array}{l}\text { Moderation of } \\
\text { extreme weather } \\
\text { events }\end{array}$ & & $\begin{array}{l}\text { Tourism } \\
\text { Recreation } \\
\text { and mental } \\
\text { and physical } \\
\text { health }\end{array}$ \\
\hline
\end{tabular}

* Ecosystems services based on The Economics of Ecosystems and Biodiversity Report (TEEB, 2011).

** It is noteworthy that this table does not aim to clarify all the possible correlations between the mentioned indicators and ecosystem services, only to highlight the predominant and more clarified correlations verified in the literature.

Source: Authors, 2020.

Thus, as observed in the literature and shown in Table 1, different indicators may be more or less important for each type of ecosystem service, because a certain structural and spatial condition of the forest remnant may be significantly more important for the provision of a typology of service compared to the other. As an example we can mention the size of the remainder; this condition is important for the provision of all types of ecosystem services, however, it is essentially more important for provision, regulation, and habitat services than for cultural services, since the latter are less limited to be provided even in small areas.

Therefore, to evaluate the supply potential of a given typology of ecosystem service 
in each mapped forest remnants were developed one index to each type of Ecosystem Service (Supply, Regulation, Habitat, and Cultural), considering the correlation between the mentioned indicators. To do so, each indicator received a weighting of 0 to 10 , according to its classification, as shown in Table 2.

Table 2 - Correlation between landscape metrics and potential ecosystem services in forest remnants*

\begin{tabular}{|c|c|c|c|c|c|}
\hline \multirow[b]{2}{*}{ INDICATOR } & \multicolumn{5}{|c|}{ WEIGHTING* } \\
\hline & 1 & 3 & 5 & 8 & 10 \\
\hline Area (AREA)** & $<0,50$ & $0,50-1,00$ & $1,00-5,00$ & $5,00-20,00$ & $\begin{array}{l}> \\
20,00\end{array}$ \\
\hline Central Area Indexl (CAI) & $<5 \%$ & $5-30 \%$ & $30-50 \%$ & $50-70 \%$ & $>70 \%$ \\
\hline Circularity Index (IC) & - & - & $<0,65$ & $0,65-0,85$ & $>0,85$ \\
\hline $\begin{array}{l}\text { Distance from Neares Neigh- } \\
\text { bor (ENN) }\end{array}$ & - & $>200$ & $120-200$ & $60-120$ & $<60$ \\
\hline Springs (SPR) & - & - & não & - & Sim \\
\hline $\begin{array}{l}\text { Land use and occupation in } \\
\text { the surroundings (SUR)** }\end{array}$ & Class 4 & Class 3 & Class 2 & Class 1 & Class 0 \\
\hline Area $(\mathrm{AREA}) * *$ & $<20,00$ & $\begin{array}{l}5,00- \\
20,00\end{array}$ & $1,00-5,00$ & $0,50-1,00$ & $<0,50$ \\
\hline $\begin{array}{l}\text { Land use and occupation in } \\
\text { the surroundings (SUR)** }\end{array}$ & Class 0 & Class 1 & Class 2 & Class 3 & Class 4 \\
\hline
\end{tabular}

* Referential: AREA (Freitas, 2012); CAI (Lima; Francisco; Bohrer, 2017); CI (Nascimento, 2006); ENN (Almeida, 2008 apud Massoli; Statella; Santos, 2016); SUR (Chaves; Santos, 2009).

** the indicators "area" and "use and occupation in the surroundings" present a different valuation to cultural services, because these services are less dependent on size and are more in demand in areas with consumers of these services, that is, population; therefore, proximity to more consolidated areas is advantageous in this case.

Sources: Authors, 2020.

From this, the indexes of ecosystem service provision were calculated by the normalized sum of the values of each indicator. Considering, however, that the variables present different weights for the supply of each type of service, the Hierarchical Process Analysis Method (AHP) was used to ponder the most relevant indicators in each of the typologies of ecosystem services (supply, regulation, support or habitat and cultural services), by calculating the coefficient of the variables.

So the ecosystem service provision index is given by , where (a, b, c, d, e, f) correspond, respectively, to the variables Area, Central Area Index, Circularity Index, Distance from Nearest Neighbor, Springs, and Land Use and Occupation in the Surroundings; and 
(a', b', c', d', e', f') the coefficients associated with them, calculated by the AHP method. In the supplementary material, all steps of the execution of these methods are presented.

\section{Results}

\section{Environmental quality indicators}

In the Anhumas River Basin were mapped 176 forest fragments. These fragments cover an area of 862,24 ha, representing only $5.90 \%$ of the total area of the basin, and are divided into three basin regions: high, medium, and low, being $70.0 \%$ in the low course, $14.8 \%$ in the middle and $15.2 \%$ in the high course.

More than $80 \%$ of the fragments present an area of up to 5 ha (medium size). The maximum size identified in a fragment was 236.90 ha, however, as verified in Figure 2a there is a very small number of fragments with an area of more than 20 ha (adequate area). Despite the reduced number, these remnants are extremely significant, since they contribute to the greatest number of forested areas. Besides that, only $33.36 \%$ of the fragment area consists of a central area, while $66.64 \%$ represents edge area; as Figure $2 \mathrm{~b}$ shows, this implies the high percentage of edge areas, highly subject to external pressures. In addition, it was identified that the fragments of the very small and small area classes have no central area; the central area index in the medium and good remnants is very small, respectively 3.65 ha (1.6\% of the area) and $34.93(16.4 \%)$. Only the remnants of adequate size, over 20 ha, were quite significant in terms of the central area $(62.7 \%)$. 
Figure 2 - Environmental indicators: Total and Central Area, Circularity Index, and Distance from the nearest neighbor
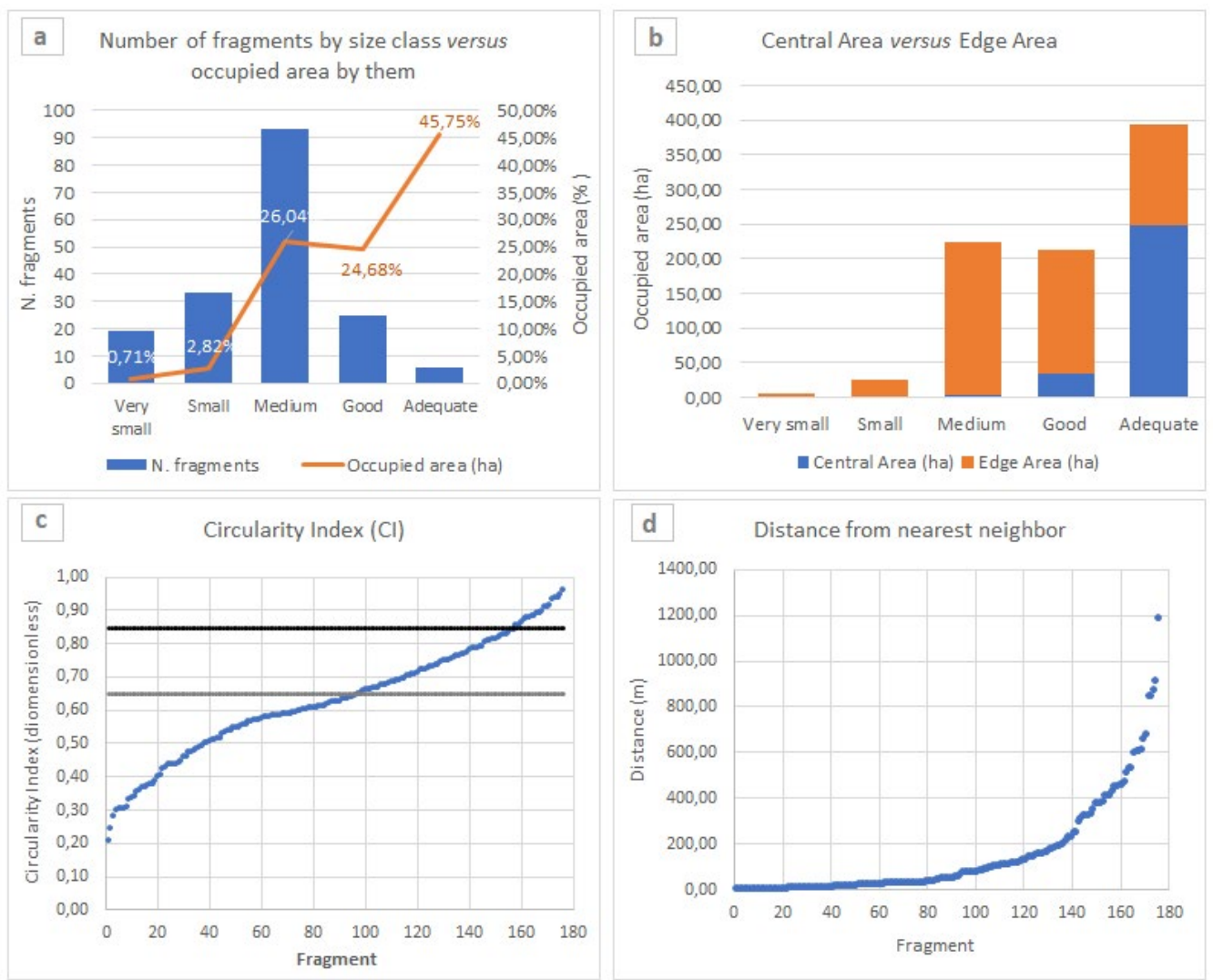

Source: Authors, 2020.

Fragments with the greater central area will be essential for the composition of a landscape that seeks to maintain the integrity of its natural vegetation cover since the density of edges will be smaller and less susceptibility to edge effects (SILVA, MELO, 2014). However, in cases where the edge area/ central area ratio is high, the correct handling of these fragments is indispensable, seeking above all to soften the edge effect an increase of the effective habitat area for the species.

In turn, most of the fragments exhibited circularity indices below 0.65 classified into elongated $(53,9 \%)$, followed by moderately elongated fragments $(35.2 \%)$ and rounded ones (10.8\%) (Figure $2 \mathrm{c}$ ). The more rounded a fragment, the greater its degree of compaction, which maintains its central region equidistant from the edge and decreases its vulnerability to external pressures (FENGLER et al., 2015).

It was identified that $52.8 \%$ of the fragments of the Anhumas River Basin are up to 60 meters away from their nearest neighbor. There are $14.2 \%$ and $10.2 \%$ with a distance 
to the nearest neighbor between $60-120 \mathrm{~m}$ and $120-200 \mathrm{~m}$, respectively, while $22.7 \%$ of the fragments have a distance greater than $200 \mathrm{~m}$ from their nearest neighbor. Figure $2 \mathrm{~d}$ shows the degree of isolation of each remnant, that is, the distance between each fragment and its nearest neighbor (MASSOLI; STATELLA; SANTOS, 2016). It is noted that this is a very variable measure, which may be related to distinct land-use and land use patterns throughout the basin; besides, the large occurrence of fragments at close distances from their nearest neighbor should be monitored, as this may often indicate that remnant before continuous has been divided into another fragment yet.

It was also found that most of the forest remnants do not have springs in their interior, they are only $17.0 \%$ with springs compared to $83.0 \%$ of the remnants without it. Regarding the degree of land use and occupation in the surrounding area, 90,9\% of the remnants presented an environment classified as highly modified (Class 4); followed by $3.4 \%$ with high modification (Class 3 ); $4.5 \%$ of medium modification (Class 2 ) and, finally, only $1.1 \%$ as low modification (Class 1 ).

\section{Evaluation of priority ecosystem services}

The execution of the AHP method (see supplementary material) resulted in coefficients for each variable considered, so that the indices of ecosystem services were given by the following equations (II, III, IV, V), where the variables are: Area (AREA); (b) Central Area Index (CAI); Circularity Index (CI); Distance from the nearest neighbor (ENN); Springs (SPR); Land Use and Occupation in the Surroundings (SUR):

$$
\begin{aligned}
\text { Supply Services }=\mathrm{Sab}= & (0,209 \cdot \mathrm{AREA}+\text { 0,281.CAI }+ \text { 0,111.CI + 0,078.ENN + } \\
& \text { 0,290.SPR + 0,031.SUR) (II) }
\end{aligned}
$$

Regulating Services $=$ Sreg $=(0,219 \cdot$ AREA $+0,277 \cdot \mathrm{CAI}+0,070 \cdot \mathrm{CI}+0,121 \cdot \mathrm{ENN}$$$
+0,199 \cdot \text { SPR }+0,114 \cdot \text { SUR) (III) }
$$

$$
\begin{aligned}
\text { Support services }=\text { Shab }= & (0,216 . \mathrm{AREA}+0,309 . \mathrm{CAI}+0,128 . \mathrm{CI}+0,221 . \mathrm{ENN}+ \\
& 0,055 . \mathrm{SPR}+0,071 . \mathrm{SUR})(\mathrm{IV})
\end{aligned}
$$

Cultural Services $=\mathrm{Scul}=(0,284 \cdot \mathrm{AREA}+0,099 \cdot \mathrm{CAI}+0,071 \cdot \mathrm{CI}+0,056 \cdot \mathrm{ENN}+$ $0,121 . S P R+0,369 . S U R)(V)$

Figure 3 presents the results obtained from the calculation of the index of ecosystem services. It can be observed that there were no fragments classified with a very low index of supply in any of the typologies of ecosystem services. Most concentrated on low to medium rates. From the analytical point of view (full view of the territory), the advantages of applying the concept of an ecosystem or environmental services are that they can provide a systematic relationship of the most relevant ecosystemic components and processes, analyzing the dependencies that human societies have on them (DE GROOT, 2006).

The high potential for provision in these remnants was predominantly associated with cultural services. This is mainly due to the location conditions of these remnants: in a highly urbanized environment, or very close to it. However, this does not necessarily imply a low potential for the provision of other types of services. As can be seen from Figure 3, many forest remnants have a high potential for the provision of all types. In 
these cases, it is up to public managers to analyze what is the greatest demand, supply, regulating, support, or cultural services, and invest in it.

Figure 3 - Index of ecosystem service provision by class in each forest remnant
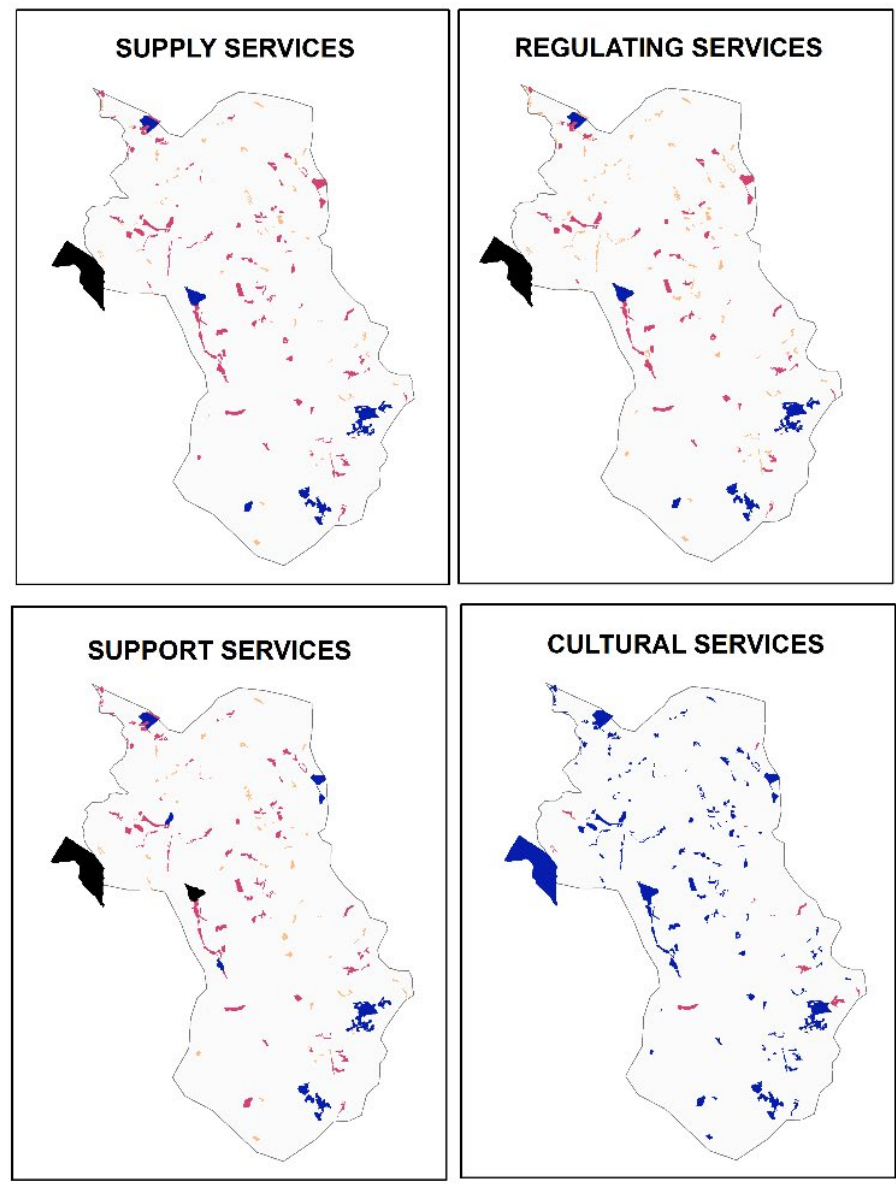

\begin{tabular}{|c|c|c|c|c|c|}
\hline Index & Ranking & Supply & Regulating & Support & Cultural \\
\hline $0,00-0,20$ & Very low & - & - & - & - \\
\hline $0,20-0,40$ & Low & $36,4 \%$ & $44,9 \%$ & $33,0 \%$ & - \\
\hline $0,40-0,60$ & Medium & $58,0 \%$ & $49,4 \%$ & $59,1 \%$ & $9,1 \%$ \\
\hline $0,60-0,80$ & High & $5,1 \%$ & $5,1 \%$ & $6,8 \%$ & $81,8 \%$ \\
\hline \multirow[t]{2}{*}{$0,80-1,00$} & Very high & $0,6 \%$ & $0,6 \%$ & $1,1 \%$ & $9,1 \%$ \\
\hline & Total & $100,0 \%$ & $100,0 \%$ & $100,0 \%$ & $100,0 \%$ \\
\hline
\end{tabular}

Source: Authors, 2020.
Service Provising
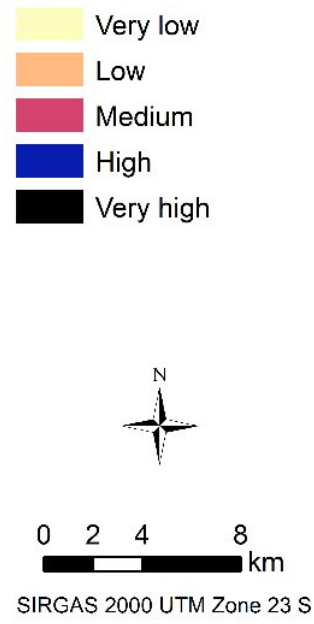

SIRGAS 2000 UTM Zone $23 \mathrm{~S}$
Potential for the
provision of

ecosystem services according to the indices 


\section{Discussion}

The high number of fragments in a relatively small area, such as this river basin, indicated an intense process of fragmentation of the landscape. When fragmented and isolated, the natural areas present little resemblance to the original balanced habitat and begin to interact more effectively with the diverse environments in the environment. In this way, these areas become even more vulnerable to the edge effect, intensifying the habitat alterations, and increasingly characterizing the environment (OLIVEIRA et al., 2015).

The area of the fragments is one of the most important parameters related to the diversity and richness of the species in the remaining areas; This is due to the fact that these fragmented areas may become too small to harbor certain species that require larger extensions to survive (CALEGARI et al., 2010; PIROVANI et al., 2014). As observed in this study, in the Anhumas River Basin predominates small to medium size remnants, less than 5.00 ha. Besides that, Pirovani et al. (2014) carried out this same finding identified in this study when observing that the relationship between the number of fragments and the area they occupy is inversely proportional, that is, although fragments of a class of small size present a larger number of spots the greater representativeness of forest areas comes from larger fragments.

According to Santos et al. (2016) the predominance of small fragments, that is, of a small area, is a worrying factor and indicator of a threat to the conservation of biodiversity; This is because, due to the edge effect from forest fragmentation, the small fragments can be easily extinguished. However, the larger fragments also need special attention regarding their preservation, since the activities developed in the surroundings can influence the vegetation, causing their suppression and corroborating to reduce the size of these fragments (LOURENÇO et al., 2015).

The edge effects include changes in the physical and biological structure of these forest remnants, which tend to penetrate the fragment, de-characterizing their original conditions. These changes include microclimate changes, manifested by the higher incidence of solar radiation and winds; moisture reduction; changes in species distribution, and abundance; loss of microbiological diversity of soil, flora and fauna; increased susceptibility to invasive species; changes in ecological relationships (SAMPAIO, 2011; HAMBERG; LEHVÄVIRTA; KOTZE, 2009; BORGES et al., 2004; BRASIL, 2003).

The low values of the central area identified in the fragments studied (only 33,36\% of the total area) demonstrated the high degree of fragility of these remnants. A study by Cabacinha and Castro (2009) in fragments of Brazilian Cerrado showed that the metrics of the central area showed positive correlations, indicating that the larger the area of the interior fragment, the greater the floristic diversity of the same. Santos et al. (2016) point out that sometimes the small fragments may even have enough total area to maintain certain species, however, not for long periods. In this way, the fragments must present not only a larger total area but also higher values of the central area.

The fact that most of the remnants in Anhumas River basin present an elongated and moderately elongated shape further emphasizes their high fragility. Cabacinha and 
Castro (2009) emphasize that, according to their study, the smaller the perimeter of the relation with the area, the greater the diversity of the fragment. It can be stated that the inverse is valid for the circularity index since it considers the area to the perimeter of the fragment; therefore, higher IC values may indicate greater genetic diversity in the fragment.

The connectivity factor, evaluated by the distance from the nearest neighbor, is also essential for the maintenance of gene flow and biodiversity in the remaining areas. Isolation of fragments causes loss of biological diversity and is directly correlated to the lowest genetic diversity; also, it increases the risk that these remaining areas will be populated by species of invasive plants (SILVA; MELO, 2014; CABACINHA; CASTRO, 2009).

Because it is a predominantly urban region, it was identified that most of the forest fragments present in the Anhumas Basin are surrounded by areas of high and/or very high modification, classified as such due to characteristics such as deforested and/or degraded areas, streets, exposed soil and buildings. (CHAVES; SANTOS, 2009)). Fengler et al. (2015) identified that in the Jundiai-Mirim River basin this is also a trend; that is, the proximity between forest areas and built-up areas has increased between 2001 and 2013.

Regarding the water production inside the fragments, only $17,0 \%$ of them present springs. This is not due to the possible low number of springs in the basin, on the contrary, there are many springs mapped in the municipality of Campinas. However, despite the high density of watercourses and springs, many of them are unprotected (SILVA, 2020).

Cabacinha and Castro (2009) emphasize, finally, that the quality of fragments is largely associated not only with an isolated indicator but with their combination; for example, that small fragments may present low diversity when isolated or in an impermeable matrix (which does not allow gene flow); however, on the other hand, fragments of the same area may present high diversity if they are well connected and in a matrix that allows such genetic flows.

Holt et al. (2015) point out that there is great potential for the provision of ecosystem services in urban environments. Thus, the role of urban planning is essential in determining which priority ecosystem services are demanded, the current availability of remaining green spaces and how, and in what spatial distribution they can contribute to the provision of such services in an efficient and accessible manner.

As verified by the results of the study, in the Anhumas River basin, the predominant potential services refer to cultural services. This is directly related to the conditions of this basin, verified from the analyzed indicators: forest fragments of very small size and surrounded by a high degree of land use and occupation, with consolidated forms of occupation such as urban, paved areas, constructions. These conditions can limit the supply of other services that demand more restricted conditions such as habitat for endemic species and food and water production.

Thus, according to Raimundo and Sarti (2016), these services in urban parks are especially related to leisure and tourism (cultural services) and, for such, parks are one of the most important urban public space equipment for leisure practices, enabling opportunity for an acknowledgment, attachment, and reintegration with nature, refuge amid of urban chaos, etc. 
However, in addition to the provision of cultural services, other ecological functions have considerable potential and can be prioritized in Anhumas River Basin, especially considering the general conditions of the basin: erosion prevention and silting in bodies of water; reduction of soil compaction by rainfall and increased rainfall infiltration; habitat supply and mitigation of heat islands (HERZOG; ROSA, 2010).

In Latin American cities, in face of other issues that become a priority for environmental values, management and planning for biodiversity and ecosystem services are still little known and evaluated (MUÑOZ; FREITAS, 2017). Therefore, the analysis presented in this study functions as an important tool to support environmental management. Besides, the identification of ecosystem services provided in certain location makes possible, among other alternatives, the establishment of programs for Payment for Environmental Services (PES).

Accords to Calderón-Contreras and Quiroz-Rosas (2017) "future efforts to secure the long-term provision of urban ecosystem services (UES) should be based on nontraditional approaches to urban planning. A framework based on a distinction between the type and potential of different UES produced at different scales may facilitate the interaction of different stakeholders in urban governance, while at the same time engaging people in urban settlements in conservation and stewardship efforts."

Davies et al. (2018), emphasize that in the case of Payment for Ecosystem Services programs of urban forests, the ideal is the establishment of partnerships between the public and private sectors, in a way that involves the citizen. The authors conclude that private institutions (companies) have high potential to act as financiers of ecosystem services in urban forests; provided such programs adequately incorporate social, environmental, and business aspects; for this, they suggest investing in pilot projects of this type, starting in the central regions of the municipalities.

\section{Conclusions}

Analyzing the results obtained in the present work it can be concluded that:

a) Employing the analysis of the indicators, it was identified that, although they presented medium sizes, the analyzed fragments have low circularity indices and little representativeness of central area, being, therefore, more subject to edge effect, which can compromise the stability and self-sustainability of the forest fragments in the ba$\sin$. Despite this, most of them are not isolated, which may indicate a potential for the implementation of management and management measures such as ecological corridors.

b) Considering the conditions indicated by the landscape metrics, to mitigate the edge effect on forest fragments in the Anhumas River Basin, it is suggested to invest in management actions that promote the effective connectivity of the remnants, to contain the forest fragmentation phenomenon and ensure the stability of the forest remnants. When this is not possible due to the consolidated conditions of use and occupation in the soil, actions for the environmental recovery of these fragments are suggested, such as: mitigation of environmental impacts in the surroundings, isolation of areas critically 
degraded from human pressure, floristic enrichment, among others.

c) Despite being in an urban area, urban forest remnants are still important for the provision of essential ecosystem services. The application of the AHP method allowed to identify that in the Anhumas River Basin, the priority ecosystem services developed by the forest remnants or to be developed by them are especially cultural services, followed by supply and support services. Given this information, municipal environmental management can prioritize the best management actions for each of these remnants, to take advantage of the maximum potential of each one of them.

d) To optimize the potential of these remnants according to the indexes of ecosystem service provision, it is suggested, for example, the following actions for each typology: (1) Cultural - recovery of the degraded remnants and investment in leisure infrastructures such as kiosks, hiking trails, playground, picnic areas, and outdoor sports; (2) Supply - verification of the physical-chemical quality of the soil, recovery of degraded areas; implementation of agrosilvipastoral system and community vegetable gardens; (3) Support - recovery of degraded areas and floristic enrichment to attract fauna; (4) Regulating - recovery of degraded areas (e.g. containment of erosion, rainwater disciplining, floristic restoration).

e) A certain group of forestry remnants have a high potential to provide all these types of services, it is up to public management, therefore, the decision making about which service to prioritize in these areas with diverse potentials. For this, it is necessary to investigate further what are the main environmental demands and problems in the area surrounding the forest and actions in which directions will bring more significant results for the improvement of the environmental quality in the basin and of the local population.

\section{Acknowledgement}

To the Foundation for Research Support the State of Sao Paulo (FAPESP) for the financial support for the execution of the research and the support of the Coordination of Personal Improvement of Higher Education - Brazil (CAPES).

\section{References}

ANDERSSON, E. et al. Reconnecting cities to the biosphere: stewardship of green infrastructure and urban ecosystem services. Ambio, v. 43, n. 4, p. 445-453, 2014.

BENEDICT, M. A; McMAHON, E. T. Green Infrastructure: Smart Conservation for the 21st Century. Washington, DC: Sprawl Watch Clearinghouse Monograph, 36 p, 2006.

BENNETT, E.M. Research frontiers in ecosystem service science. Ecosystems, v. 20, n. 1, p. 31 37, 2016.

BORGES, L. F. R. et al. Inventário de fragmentos florestais nativos e propostas para seu manejo 
e o da paisagem. CERNE, Lavras, v.10, n.1, p.22-38, 2004.

BRASIL. MINISTÉRIO DO MEIO AMBIENTE. SECRETARIA DE BIODIVERSIDADE E FLORESTAS. Fragmentação de ecossistemas: Causas, feitos sobre a biodiversidade e recomendações de políticas públicas. Brasília: MMA, 2003. Disponível em: < http://www.mma.gov. br/estruturas/chm/_arquivos/fragment.pdf>. Acesso em 26 fev. 2017.

BRIGUENTI, E. C. O uso de geotecnologias na avaliação da qualidade ambiental da Bacia do Ribeirão Anhumas, Campinas/SP. 2005. 140 f. Dissertation (Master in Geography) - University of Campinas (UNICAMP), Institute of Geosciences, Campinas.

CABACINHA, C. D. CASTRO, S. S. Relationships between floristic diversity and vegetation indices, forest structure and landscape metrics of fragments in Brazilian Cerrado. Forest Ecology and Management, v. 257, p. 2157-2165, 2009.

CALDERÓN-CONTRERAS, R.; QUIROZ-ROSAS, L.E. Analysing scale, quality and diversity of green infrastructure and the provision of Urban Ecosystem Services: A case from Mexico City. Ecosystem Services, v. 23, 127-137, 2017.

CALEGARI, L. et al. Analysis of the dynamics of forest fragments in the city of Carandaí, MG, for forest restoration. Revista Árvore, v. 34, n. 5, p. 871-880, 2010.

CAMPINAS. Mapa de Vegetação Natural. Campinas: FUNCAMP, 2015. Escala 1:10.000. Disponível em: <https://geoambiental.campinas.sp.gov.br/pmapper/map_svds.phtml?config=svds $>$. Acess in 20 mar. 2019.

CAMPINAS. Portal Geoambiental. Disponível em: < https://geoambiental.campinas.sp.gov. br/>. Acess in 15 jul. 2018.

CAMPINAS. The city. Available in: < http://www.campinas.sp.gov.br/governo/seplama/dados-do-municipio/cidade/>. Access in: 09 Nov. 2018.

CARPI JR., S et al. Levantamento de riscos na bacia do ribeirão das Anhumas. In: Projeto Anhumas. Campinas - SP: IAC, p. 262-302, 2006.

CARPI, S.; DAGNINO, R. S.; SCALEANTE, O. A. F. Percepção e Mapeamento de Riscos em Campinas/SP. Olam Ciência \& Tecnologia, v. 7, n. 1, p. 545-568, 2007.

CHAVES, H. M. L.; SANTOS, L. B. Land use, landscape fragmentation, and water quality in a small watershed. Revista Brasileira de Engenharia Agrícola e Ambiental, v. 13, p. 922-930, 2009.

CHELLERI, L.; SCHUETZE, T.; SALVATI, L. Integrating resilience with urban sustainability in neglected neighborhoods: challenges and opportunities of transitioning to decentralized water management in Mexico City. Habitat International, v. 48, p. 122-130, 2015.

DAVIES, H. J. et al. Business attitudes towards funding ecosystem services provided by urban forests. Ecosystem Services, v. 32, p. 159-169, 2018. 
DE GROOT, R. S. Function-analysis and valuation as a tool to assess land-use conflicts in planning for sustainable, multi-functional landscapes. Landscape and Urban Planning, v. 75, p. 175-186, 2006.

DE OLIVEIRA, J. P. et al. Cities and biodiversity: Perspectives and governance challenges for implementing the convention on biological diversity (CBD) at the city level. Biological Conservation, v. 144, n. 5, p. 1302-1313, 2011.

EMPLASA. COMPANY PAULISTA DE PLANEJAMENTO METROPOLITANO S/A. Cartographic Products: Digital Orthophotos. São Paulo, 2010.

ETTO, T. L. et al. Landscape ecology of the forests of Ribeirão das Pedras watershed - Campinas, São Paulo State. Revista Árvore, v. 37, n. 6, p. 1063-1071, 2013.

EWERS, R.M.; DIDHAM, R.K. Confounding factors in the detection of species responses to habitat fragmentation. Biological Reviews, v. 81, n. 1, p. 117-142, 2006.

FENGLER, F.H. et al. Environmental quality of forest fragments in Jundiaí-Mirim river basin between 1972 and 2013.Revista Brasileira de Engenharia Agrícola e Ambiental, v. 19, n. 4, p. 402-408, 2015.

FERNANDES, M. et al. Ecologia da Paisagem de uma Bacia Hidrográfica dos Tabuleiros Costeiros do Brasil. Floresta e Ambiente, v. 24, e00025015, 2017.

FERNANDES, M.; FERNANDES, R. D. M. Análise Espacial da Fragmentação Florestal da Bacia do Rio Ubá - RJ. Ciência Florestal, v. 27, n. 4, p. 1429-1439, 2017.

FISCHER, J.; LINDENMAYER, D.B. Landscape modification and habitat fragmentations: a synthesis. Global Ecology and Biogeography, v. 16, p. 265-280, 2007.

FRANKLIN, A.B.; GUTIÉRREZ, R.J. Spotted owls, forest fragmentation, and forest heterogeneity. Studies in Avian Biology, v. 25, p. 203-220, 2002.

FREITAS, E. P. et al. Environmental indicators for areas of permanent preservation. Revista Brasileira de Engenharia Agrícola e Ambiental, v. 17, v. 4, p. 443-449, 2013.

HAASE, D. et al. A quantitative review of Urban ecosystem service assessments: concepts, models, and implementation. Ambio, v. 43, n. 4, p. 413-433, 2014.

HAMBERG, L.; LEHVÄVIRTA, S.; KOTZE, D. J. Forest edge structure as a shaping factor of understorey vegetation in urban forests in Finland. Forest Ecology and Management, v. 257, p.712-722, 2009.

HERRMANN, B. C.; RODRIGUES, E.; LIMA, A. A paisagem como condicionadora de bordas de fragmentos florestais. Revista Floresta, v. 35, n. 1, p. 13-22, 2005.

HERZOG, C. P. A multifunctional green infrastructure design to protect and improve native biodiversity in Rio de Janeiro. Landscape Ecology Engineering Journal, v. 12, p. 141-150, 2016. 
HERZOG, C. P.; ROSA, L.Z. Green infrastructure: Building sustainability and resilience in urban landscapes. Revista LABVERDE, v. 1, p. 92-115, 2010.

HOLT, A. R. et al. Understanding spatial patterns in the production of multiple urban ecosystem services. Ecosystem Services, v. 16, p. 33-46, 2015.

KREMER, P. et al. Advancing the frontier of urban ecosystem services research. Ecosystem Services, v. 12, p. 149-151, 2015.

LAMBIN, E. F; MEYFROIDT, P. Global land-use change, economic globalization, and the looming land scarcity. Proceedings of the National Academy of Sciences of the USA, v. 108, n. 9, p. 3465-3472, 2011.

LAWLEY, V. et al. Site-based and remote sensing methods for monitoring indicators of vegetation condition: An Australian review. Ecological Indicators, v. 60, p. 1273-1283, 2016.

LOURENÇO, R.W. et al. Use of fuzzy systems in the elaboration of an anthropic pressure indicator to evaluate the remaining forest fragments. Environmental Earth Science, v. 74, p. 2481 2488, 2015.

MAES, J. et al. More green infrastructure is required to maintain ecosystem services under current trends in land-use change in Europe. Landscape Ecology, v. 30, p. 517-534, 2015.

MASSOLI, J.V.; STATELLA, T.; SANTOS, V.S. Estimativa da fragmentação florestal na microbacia Sepotubinha, Nova Marilândia - MT, entre os anos de 1990 a 2014. Caminhos de Geografia, v. 17, n. 60, p. 48-60, 2016.

MCPHEARSON, T., et al. Resilience of and through urban ecosystem services. Ecosystem Services, v. 12, p. 152-156, 2015.

MEA. MILENNIUM ECOSYSTEM ASSESSMENT. Ecosystems and human well-being: Biodiversity Synthesis. World Resources Institute. Washington, DC: Island Press, 2005.

MEEROW, S.; NEWELL, J.P.; STULTS, M. Defining urban resilience: a review. Landscape and Urban Planning, v. 147, p. 38-49, 2016.

MORLEY, R. J. Tropical rain forests. In: CILEK, V. Earth System: History and Natural Variability. Oxford: Encyclopedia of Life Support Systems (EOLSS), v. 3, p. 140-149, 2009.

MORO, R. S.; MILAN, E. Natural Forest Fragmentation Evaluation in the Campos Gerais Region, Southern Brazil. Environment and Ecology Research, v. 4, n. 2, p. 74-78, 2016.

MUÑOZ, A. M. M.; FREITAS, S. R. Importance of ecosystem services in cities: review of publication from 2003 to 2015. Revista de Gestão Ambiental e Sustentabilidade, v. 6, n. 2, p. 89-104, 2017.

NASCIMENTO, M. C. do et al. Mapeamento dos fragmentos de vegetação florestal nativa da bacia hidrográfica do Rio Alegre, Espírito Santo, a partir de imagens do satélite Ikonos II. Revista 
Árvore, v. 30, n. 3, p. 389-398, 2006.

NETO, R. S. et al. Caracterização da Cobertura Florestal de Unidades de Conservação da Mata Atlântica. Floresta e Ambiente, v. 22, n. 1, p. 32-41, 2015.

OLIVEIRA, A. P. G. et al. Uso de geotecnologias para o estabelecimento de áreas para corredores de biodiversidade. Revista Árvore, v. 39, n. 4, p. 595-602, 2015.

OLIVEIRA, L. S. C. et al. Edge effect in Atlantic Forest Remnants in the watershed of the river Tapacurá, Perbambuco. CERNE, v. 21, v. 2, p. 169-174, 2015.

PARDINI, R. et al. Beyond the Fragmentation Threshold Hypothesis: Regime Shifts in Biodiversity Across Fragmented Landscapes. PLOS One, v. 5, n. 10, e13666, 2010.

PICHARILlO, C.; RANIERI, V. E. L. Pagamento por Serviços Ambientai: Orientação para identificação de áreas prioritárias com foco na biodiversidade. Revista Ambiente e Sociedade, v. 22, e03033, 2019.

PIROVANI, D. B. et al. Spatial analysis of forest fragments in the Itapemirim River Basin, ES. Revista Árvore, v. 38, n. 2, p. 271-281, 2014.

RAIMUNDO, S.; SARTI, A. C. Parques urbanos e seu papel no ambiente, no turismo e no lazer da cidade. Revista Iberoamericana de Turismo, v. 6, n. 2, p. 3-24, 2016.

RANTA, P. et al. The fragmented Atlantic rain forest of Brazil: size, shape and distribution of forest fragments. Biodiversity and Conservation, v. 7, p. 84-403, 1998.

ROSA, F. S.; TORNELLO, K. C.; LOURENÇO, R.W. Selection of priority areas for payment of environmental services: an analysis at the watershed level. Revista Ambiente e Água, v. 1, n. 2, p. 448-461, 2016.

SAITO, N. S. et al. Geotecnologia e Ecologia da Paisagem no Monitoramento da Fragmentação Florestal. Floresta e Ambiente, v. 23, n. 2, p. 201-210, 2016.

SAMPAIO, R. C. N. Efeito de borda em um fragmento de floresta estacional semidecidual no interior do Estado de São Paulo. 2011. xiii, 83 f. Dissertação (Mestrado em Ciência Florestal) Universidade Estadual Paulista, Faculdade de Ciências Agronômicas, 2011.

SANTOS, A. R. et al. Geotechnology and landscape ecology applied to the selection of potential forest fragments for seed harvesting. Journal of Environmental Management, v. 183, p. 10501063, 2016.

SÃO PAULO. PAULISTA ENVIRONMENTAL SYSTEM. Land Use and Coverage of UGRHI 05 (PCJ) - 2013. Available in <http://datageo.ambiente.sp.gov.br/web/guest/inicio >. Access in: 2017.

SCHEWENIUS, M.; MCPHEARSON, T.; ELMQVIST, T. Opportunities for increasing resilience and sustainability of Urban social-ecological systems: insights from the URBES and the cities 
and biodiversity outlook projects. Ambio, v. 43, n. 4, p. 434-444, 2014.

SILVA, A. L. Analysis of the Environmental Quality of Forest Remnants through landscape metrics: A study in the city of Campinas / SP. 2020. $173 \mathrm{f}$. Master's Thesis (Master in Urban Infrastructure Systems) - Programa de Pós-Graduação em Sistemas de Infraestrutura Urbana, Pontifícia Universidade Católica de Campinas, Campinas, 2020.

SILVA, A. L.; LONGO, R. M. Influence of urbanization on the original vegetation cover in urban river basin: casy study in Campinas/SP. Brazil. Geophysical Research Abstracts,19, EGU20175368, 2017. In: EGU General Assembly, 2017, Viena.

SILVA, K. G. et al. Análise da dinâmica espaço-temporal dos fragmentos florestais da sub-bacia hidrográfica do Rio Alegre, ES. CERNE, v. 21, n. 2, p. 311-318, 2015.

SILVA, M. S. F.; MELO, R. Padrões espaciais de fragmentação florestal na FLONA do Ibura Sergipe. Revista Mercator, v. 13, n. 3, p. 121-137, 2014.

TEEB - THE ECONOMICS OF ECOSYSTEMS AND BIODIVERSITY. Manual for Cities: Ecosystem Services in Urban Management. 2011. Available in: <http//www.teebweb.org $>$. Access in: out. 2018.

TRATALOS, J. et al. Urban form, biodiversity potential and ecosystem services. Landscape and Urban Planning, v. 83, n. 4, p. 308-317, 2017.

VALENTE, R. O. A. Definição de áreas prioritárias para conservação e preservação florestal por meio da abordagem multicriterial em ambiente SIG. 2005. $121 \mathrm{f}$. Thesis (Doctorate in Forestry Resources) - University of São Paulo (USP), Piracicaba, 2005.

VIANA, V. M.; PINHEIRO, L. A. F. V. Conservação da biodiversidade em fragmentos florestais. Série Técnica IPEF, v. 12, n. 32, p. 25-42, 1998.

YILMAZ, S.; MUMCU, S. Urban Green Areas and Design Principles. In: EFE, R. et al. Environmental Sustainability and Landscape Management. Sofia: St. Kliment Ohridski University Press, p. 100-118, 2016.

YOUNG, R. et al. A comprehensive typology for mainstreaming urban green infrastructure. Journal of Hydrology, v. 519, p. 2571-2583, 2014. 
Alessandra Leite da Silva

$\square$ alessandra.leite@unesp.br

ORCiD: https://orcid.org/0000-0001-6534-2122

\section{Admilson Írio Ribeiro}

\admilson.irio@unesp.br

ORCiD: https://orcid.org/0000-0003-0655-6838

\section{Regina Marcia Longo}

$\checkmark$ regina.longo@puc-campinas.edu.br

ORCiD: https://orcid.org/0000-0002-2374-4649
Submitted on: $24 / 02 / 2020$

Accepted on: 03/02/2021

2021;24e:00121

How to cite: SILVA, A. L.; RIBEIRO, A. Í.; LONGO, R. M. Tools for prioritizing Ecosystem Services provided by fragments forest in the context of cities. Ambiente $\mathbb{\&}$ Sociedade. São Paulo, v. 24, p. 1-23, 2021. 


\title{
Ferramentas para priorização dos serviços ecossistêmicos prestados por fragmentos florestais no contexto das cidades
}

\author{
Alessandra Leite da Silva \\ Admilson Írio Ribeiro \\ Regina Márcia Longo
}

São Paulo. Vol. 24, 2021

Artigo Original

\begin{abstract}
Resumo: Os remanescentes florestais são essenciais na prestação de serviços ecossistêmicos nas cidades. No entanto, ainda são necessários parâmetros ecológicos adequados para avaliá-los. Diante disto, o presente trabalho propõe uma metodologia de avaliação do potencial de prestação de serviços ecossistêmicos por remanescentes florestais de bacia hidrográfica urbana a partir da aplicação e interpretação das métricas espaciais da paisagem utilizadas nos estudos de Ecologia da Paisagem. Para tanto, aos indicadores ambientais (área, área central, índice de circularidade, distância do vizinho mais próximo, nascentes de água, uso e ocupação no entorno) avaliados em software GIS foi aplicado o Método de Análise de Processo Hierárquico (AHP) para identificação da importância de cada parâmetro na prestação dos serviços do ecossistema e os prioritários em cada restante. $\mathrm{O}$ estudo foi executado em bacia hidrográfica de Campinas/SP, na qual verificou-se que os remanescentes florestais desenvolvem, prioritariamente, serviços ecossistêmicos de apoio ou habitat, serviços de regulação e serviços culturais.
\end{abstract}

Palavras-chave: Remanescentes florestais urbanos; análise espacial; serviços ecossistêmicos; Análise Hierárquica de Processos.

Como citar: SILVA, A. L.; RIBEIRO, A. I.; LONGO, R. M. Ferramentas para priorização dos serviços ecossistêmicos prestados por fragmentos florestais no contexto das cidades. Ambiente $\mathbb{\&}$ Sociedade. São Paulo, v. 24, p. 1-23, 2021. 


\title{
Herramientas para priorizar los Servicios Ecosistémicos prestados por fragmentos forestales en el contexto de las ciudades
}

\author{
Alessadnra Leite Silva \\ Admilson Írio Ribeiro \\ Regina Márcia Longo
}

São Paulo. Vol. 24, 2021

Resumen: Los remanentes forestales son esenciales en la provisión de

Artículo original servicios ecosistémicos en las ciudades. Sin embargo, todavía se necesitan parámetros ecológicos adecuados para evaluarlos. En vista de esto, esto trabajo propone una metodología para evaluacion del potencial de provisión de servicios ecosistémicos por remanentes forestales basado en la aplicación e interpretación de métricas espaciales del paisaje, utilizado en los estudios de Ecología del Paisaje. Para eso, a los indicadores ambientales (área, área central, índice de circularidad, distancia del vecino más cercano, manantiales, uso y ocupación en el entorno) evaluados en SIG se aplicó el Método de Análisis Jerárquico de Procesos (AHP), para identificar la importancia de cada parámetro en la provisión de servicios ecosistémicos y la prioridad en cada remanentes. El estudio fue realizado en una cuenca hidrográfica em Campinas / SP, en el que se descubrió que los remanentes forestales desarrollan, principalmente, servicios de soporte del ecosistema o hábitat, servicios de regulación y servicios culturales.

Palabras-clave: Remanentes forestales urbanos; análisis espacial; servicios ecosistémicos; Análisis Jerárquico de Procesos.

Como citar: SILVA, A. L.; RIBEIRO, A. I.; LONGO, R. M. Herramientas para priorizar los Servicios Ecosistémicos prestados por fragmentos forestales en el contexto de las ciudades Ambiente $\mathbb{\&}$ Sociedade. São Paulo, v. 24, p. 1-21, 2021.

DOI: http://dx.doi.org/10.1590/1809-4422asoc20200012r1vu2021L2AO 